RJPSSs, Vol. XLVI No.1, June 2020 ISSN: (P)0048-7325 (e) 2454-7026 Impact Factor 7.821 (SJIF)

https://doi.org/10.31995/rjpsss.2020v46i01.16

\title{
Metaphysical Stand OF THE MaHima Cult
}

\author{
Mamata Rani Pati \\ Research Scholar, N.O. U., \\ Baripada, Odisha. \\ Email:mamtaranipati22@gmail.com
}

Abstract

Even though Mahim $\bar{a}$ the cult is primarily a religious movement we can find a distinct metaphysical stand in the writings of the poet-philosopher, Bhima Bhoi, the initial exponent of the cult. It is quite important to note that there has been a strong influence of the monistic stand of the Upanisads and the sunya-centric metaphysical stand of the pancasakhaa philosophers of Odisha. In this context, the views of different reputed scholars are re-examined. The article spells out the specific metaphysical stand of the cult. Keywords: Niraakaara and nirguna Brahman, Mahima, Alekha, Sunya

Reference to this paper should be made as follows:

Received: 15.06.2020

Approved: 07.07.2020

\section{Mamata Rani Pati}

METAPHYSICAL STAND OF THE MAHIMA CULT

RJPSSs 2020, Vol. XLVI, No. 1, pp. 137-143 Article No.16

Online available at: http://rjpsss.anubooks.com https://doi.org/10.31995/ rjpsss.2020v46i01.16 
METAPHYSICAL STAND OF THE MAHIMA CULT

Mamata Rani Pati

\section{Introduction}

Brahman So far as the origin and development of this cult are concerned it owes its origin to Mahimaa Gosaain and it is said that the task of preaching the cult was solely given to Bhima Bhoi, who happens to be the chief exponent of the cult. His poems were very reached with metaphysical thoughts out of which a distinct conception reality can be worked out. And in fact, many scholars have taken an attempt in this direction. But his disciple Avadhuta Bisvanatha Baba has contributed significantly regarding his metaphysical stand which is known as Visuddhaadvaita vada. But in this article, the view of poet-philosopher Bhima Bhoi will be taken into account.

Even though Mahimaa cult is primarily a religious movement we can find a distinct metaphysical stand in the writings of the poet-philosopher, Bhima Bhoi. It is because he has talked about the ultimate reality, the universe (saAsra in his terminology) and the world (Jagat). For him the three worlds (lokas) taken together constitute SaAsaara. The entire speculative metaphysics of Bhima Bhoi has been synthesized in this following couplet where he says that there is no one higher to Mahim in this universe who has pervaded in the three worlds. "Mahimânka thâru Bida nâhin nâ saAsâre, mahimâhin âtajâta tini Jagat is. ${ }^{1}$

It is seen that the major aim of the cult was to refute the idol worship of Hinduism. But, though not directly but indirectly there does tacit acceptance of orthodox Upanishadic stands in various ways shows that since the cult came to existence much late it carries the impact of two major trends of the past, namely, Vedic and Buddhistic trends. One such example is the case of accepting the possibility of three worlds in Mahima cult was very much there in the Vedic trend which has been described as svarga, Amartya and ptla (heaven, world and under the ground) or the devaloka, martyaloka and ptlook where Gods, humans, demons live respectively.

Bhima Bhoi has categorically accepted and preached monism in respect of the ultimate reality even though various expressions are used by him for that single reality. The expressions, found to be used for the ultimate reality are 'Mahim', 'Purusa', 'Aleka', 'Suunya' and 'Brahma' etc.. Sometimes any two of the mentioned terms are also found to be used combined as, 'Sunya-Purusa', 'Sunya-Brahma', 'MahimAlexa', etc.. He has mentioned that the single reality is the Brahman which is eternal and has no parts. Do not split the Brahman because there is no second possibility. His words: 
RJPSSs, Vol. XLVI No.1, June 2020 ISSN: (P)0048-7325 (e) 2454-7026 Impact Factor 7.821 (SJIF)

https://doi.org/10.31995/rjpsss.2020v46i01.16

Brahma haiku kai marai ki sei save hotcha baai

Akhanda brahmaku khandita Makara Hikaru Kahani dui. ${ }^{2}$

Aleka, who is also conceived as the 'Mahim' is beyond comprehension. The name 'Aleka' or 'Mahim' has been attributed to the ultimate reality based on the nature of the ultimate reality. He considers that there is no language that can express reality. For this reason, the reality is named as Alekha (un-writable). The indescribability is due to the infinite nature of it. Because of this, not only the possibility of description is rejected also the scope of use of the language is restricted. Se roopaku varnivaaku valuta kathina, Aksara a vase john a sphere vachana. ${ }^{3}$ Non availability of the finite form (nhin Roopa kaanti) and as unheard (a[ti) also keeps it away from prayers and eulogies. He is not known (agochara) to anyone. The tongue cannot spell out it (a late jihad). That is why he bears the name Mahimaa. ${ }^{4}$ In the way it has been said earlier, in a similar way the Brahman has been conceived in most of the Upanisads. We can see there is a striking resemblance between the view of the following Upanisads and the view of Bhima Bhoi regarding Brahman. It has been described as formless, infinite, indescribable (anirvacaniya), not available to language and mind (yatovacanivartante, aprpya manas sah), ${ }^{5}$, etc. The Katha, Kena, and Munduka Upanisads have thought similarly in the following manner. In the Katha Upanisad it has been described as: Not by speech, not by mind, not by sight can he be apprehended. How can he be comprehended except by him who says, 'He is'? ${ }^{6} \mathrm{He}$ can be comprehended only by those who affirm that ' $\mathrm{He}$ is'. "The self as the knowing subject can never become an object. It can be realized through Yoga. While He transcends the ordinary means of apprehension, He can be immediately experienced through Yoga, and for such apprehension faith in His existence is an indispensable condition." ${ }^{\text {In }}$ the Kena Upanisad it has been described as:

Na tatra cakcur gacchati a vg gacchati no mana\% Na vidmona Vijnmo yathaitad anuaicy ${ }^{8}$

(There the eye goes not, speech goes not, nor the mind; we know not, we understand not how one can teach this.) It is such that to this visibility, audibility and conceivability are denied. So also it is not possible to grasp or know or explain. On the whole, it is beyond comprehension and deliberation. In a similar manner, it has been described in the Mundaka Upanisad that " He is not grasped by the eye nor even by speech nor by other sense-organs, nor by austerity nor by work." (nacakcuc g[hyate npi vc nnyair devai\% tapas karmaG va). ${ }^{9}$ Moreover this view resembles with the Kathoupanisadic stand that Brahman is soundless, colorless, tasteless, eternal, odorless, beginningless, and endless. Also, the view resembles with Mndkya 
METAPHYSICAL STAND OF THE MAHIMA CULT

Mamata Rani Pati

Upanisad where Brahman is described as unthinkable, ungraspable, and unnameable. The concept of Dajjaln of the Chndogya Upanisad also expresses similar thought that it is the essence of everything and it also that to which everything dissolves. Thus it is difficult to distinguish between the Upanisadic concept of 'NirguGa Brahman' and the concept of 'Brahman' of Mahimcult.

Bhima Bhoi also maintains that since Brahman is omnipresent, the formless Brahman is also available having forms. The world of objects is his creation. He cannot be isolated from the created objects. The impersonal Brahman also found to be personal being present in each and everything (Sarva gate bije Hari). ${ }^{10}$ In the personal form it is known as jiva Brahman. Thus the expression Brahman above Brahman (Brahman are Brahman) ${ }^{11}$ refers to the two forms of the Brahman, namely, jiva Brahman and Brahman. As jiva Brahman, it resides in everyone irrespective of good or wicked or demon-like beings. ${ }^{12}$ Patnaik mentions the view of Mahima dharma that "The visible universe is the manifestation of the Mahima (glory) of Parama Brahman. All the things of the world are illuminated and made conscious due to the direction of the conscious Almighty

This above-mentioned view of Mahima cult is very much like the view found in the opening line of the Iúa Upanisad that lúâ is pervaded in the each and every object of this world (Iûâ vâsyam idam sarvam yat Kim ca jagatyâm Jagat). And there is also striking resemblance with the classic expression of the Chândogya Upanisad: Sarva khalu am Brahma. ${ }^{13}$

The higher Brahman or the Brahman is not affected by its transformation to the lower version in the form of jivas or particulars. Panigrahi puts it as "Therefore the witnessing self is not bound - that which is bound is the lower self, the doer and the enjoyer. In this sense, Mahima Alekha not only contains the individual and the universe within its own self but remains as the eternal witness.

$p i G$

a brahmâG

aku garbhagatare dharichha heSakala but are sâkciparâye purichha ${ }^{14}$

Brahman has been described as the witnessing self in Upanisads as well in the Gita. "Two birds, companions (who are) always united, cling to the self-same tree, of these two, the one eats the sweet fruit and the other looks on without eating,". ${ }^{15}$ Bhagavad Gita (XIII- 22)says: 'The supreme spirit in the body is said to be the witness, the permitter, the supporter, the experiencer, the Great Lord and the Supreme Self' ${ }^{16}$

Thus it is marked that there has been a great deal of resemblance between 
RJPSSs, Vol. XLVI No.1, June 2020 ISSN: (P)0048-7325 (e) 2454-7026 Impact Factor 7.821 (SJIF)

https://doi.org/10.31995/rjpsss.2020v46i01.16

the Upanishadic conception of reality and the Mahima concept of reality so far as the inexpressibility aspect of the ultimate reality and the creator-creation relationship are concerned. But there is also a remarkable difference between these two trends regarding another aspect of the same reality. That is, in Mahima cult reality has been treated as Sunya (void) whereas in the Upanisads reality has treated as Poorna (Whole).

\section{Reality as Sunya}

The most important feature of Mahima philosophy is its sunya-centric metaphysics. The cult admits a single ultimate Absolute and advocates absolutemonism. But for them, the ultimate principle or the supreme is Sunya Purusa or Sunya Brahman. The emphasis on the concept of sunya is attached conspicuously in these two of the books, namely, Brahma-Nirupama Gita and Srutinisedha Gita. In fact, the opening line of the former mentions that the almighty, Rekha purusa is itself void or the great void ('sunya sunya mahaasunya alekha purusa'). Similarly, in the latter one, it is mentioned that Mahaasunya-Brahman is beyond all desires, attachments, predications, etc. ${ }^{17}$ When the ultimate reality is treated to be infinite, indescribable, and un-writable it is also treated as non-categorical. The inadequacy of language and the non-categorical nature is expressed by the term 'Sunya'. This Sunya is identified with Mahima and treated as the Sunya Brahman which is the beginning of everything and also the ultimate end. As Sunya Brahman it is beyond comprehension. In the Brahm-Nirupama Gittâ, it has been said: He (the ultimate reality) is supposed to be the great void (mahâsunya) which should be conceived as qualityless $(\operatorname{nirgu} G a)$. No one can know his real nature as his real essence is Sunya.

They are very much against idol worship. So they have not taken any attempt to find a symbolic form of God to be worshipped. In this respect the cult avoids one of the major features of theism, that is, idol worship. It is taken for granted that the ultimate principle cannot take any form and for that reason, God should not be traced either in heaven or in the earth (inside temples). God is Alekha (indescribable) and Sunya (void). In respect of the use of the concept of Sunya and Alekha, many scholars have marked the close similarity between the bhajans of Odia panchasakhaa and their contemporary writers and the bhajans of Bhima Bhoi. For example, the concept sunya has been significantly used in the Sunya Samhitaa of Achutananda Dasa. ${ }^{18}$ Further it can be pointed out that at least thirty years prior to Bhima Bhoi, one of the pancasakhaa, Jagannatha Dash has described the ultimate one to be sunny in the words which have been translated as Omkara is Parama-Sunya; all our activities are sunya too.The prayers and meditations are sunya. The forms and fancies are sunya.... The celestial bodies like the sun and moon are nothing but 
sunya. The empirical world along with the animate and inanimate beings is in sunya. ${ }^{19}$ So far as the uses of the term 'Sunya-Brahman' is concerned there has a great deal of resemblance in the writings of by Achyutananda and Bhima Bhoi. The former writes: It has no shape, no color is invisible and without a name.This Brahman is called Sunya-Brahman. ${ }^{20}$ The later writes: The invisible Brahman is one and unique,...This is what is called sunya and mahaasunya, ... . ${ }^{21}$ Beyond word he is and beyond thought, His body is sunya,... . ${ }^{22}$

Nobody knows His exact name, as the essence of the higher Brahman is Sunya.(Brahma are Brahma sûnya rahichhi marmas, kehi a jâne tânka ninja nâmaku." 23

Thus it can be pointed out that even though a distinct metaphysical stand can be worked out in respect of the Mahima cult but the influence of the Upanisadic metaphysics, as well as the panchasakha writers, cannot be denied. But it is seen that a group of scholars including Patnaik emphasize on the view that 'Mahima philosophy is a continuation of the medieval philosophical tradition of Odisha.' ${ }^{24}$

\section{References}

1 Brahmanirupana Gitaa, X, 102

2 Bhajanamaalaa, 219

3 Brahma-Nirupama Gitaa, III,54

4 Stutichintamani, 6

5 Taittiriya Upanisad 11, 4, 1

6 Katha Upanisad - naive vcna manas prptukayo na cakuc, astti bruvato'nyatra kathaA tad upalabhyate. II.3.12

7 Radhakrishnan, S., The Principal Upanisads, Harper Collins Publishers India, 1999 , p. 646

8 I. 36

9 3-1-8

10 Sruti Chintamani, 61

11 Bhajanamala, $\mathbf{1 7}$

12 Sruti Chintamani, 47

13 III, 14, 1.

14 Bhajanamala, 108

15 Svetasvatara Upanisad, IV, 8

16 Panigrahi, S.C., Bhima Bhoi and Mahima Darsana, Santosh Publications, Cuttack, 1998, p. 29. 
RJPSSs, Vol. XLVI No.1, June 2020 ISSN: (P)0048-7325 (e) 2454-7026 Impact Factor 7.821 (SJIF) https://doi.org/10.31995/rjpsss.2020v46i01.16

17 Bhima Bhoi, Srutinisedha Gita, 1.

18 Achyutananda Dash, Sunya Samhitaa, $7^{\text {th }}$ Chapter. Darmagrantha Store, Cuttack.

19 Jagannatha Dash, Tula Bhinaa, III,12.1.

20 Achyutananda Dasa, Sabda-Brahma Samhitaa, $4^{\text {th }}$ canto.

21 Brahma-nirupana Gita, $3^{\text {rd }}$ canto

22 Stuticintamani, 46

23 Bhajanamamaala, 17.

24 Patnaik, Tandra, God as Sunya, D. K.Print World, 2016, p. 63. 